\title{
REASONS AND CONSEQUENCES OF RESTRUCTURING THE TEXTILE INDUSTRY OF UKRAINE IN THE CONDITIONS OF GLOBALIZATION
}

\author{
Vasyl H. Gerasymchuk ${ }^{1 *}$, Svitlana V. Andros ${ }^{2}$, Anna V. Tsymbal ${ }^{3}$
}

${ }^{1}$ National Technical University of Ukraine

"Igor Sikorsky Kyiv Polytechnic Institute”, NTUU “KPI”, FMM, IED, Kyiv, Ukraine

2 National Science Center "Institute of Agrarian Economics", Kyiv, Ukraine

${ }^{3}$ National Technical University of Ukraine

“Igor Sikorsky Kyiv Polytechnic Institute”, Poliekhnichna, NTUU „KPI“, FMM, DTAE, Kyiv, Ukraine

* e-mail: gerasimchuk@kpi.ua

\begin{abstract}
The article reveals the causes and consequences of accumulated problems in the development of the textile industry of Ukraine. The analysis of the state of the global textile market is presented. The processes of transferring centers of influence in the industry mainly from developed countries to developing countries are studied. The critical dependence of textile production on imported raw materials and semi-finished products is established. Attention is drawn to the need to strengthen the domestic raw material base, the revival and cultivation of flax, industrial hemp. The state of the implementation of foreign trade transactions in the industry is characterized the intensity of the flow of investment to strengthen its potential is investigated. Attention is focused on the need to strengthen the role of the state in supporting the development of the textile industry. Recommendations on further restructuring of the textile industry as an effective tool to increase its competitiveness have been developed.
\end{abstract}

Key words: foreign trade turnover, globalization, competitiveness, national market, restructuring, textile industry.

\section{RAZLOZI I POSLEDICE RESTRUKTURIRANJA TEKSTILNE INDUSTRIJE UKRAJINE U USLOVIMA GLOBALIZACIJE}

\begin{abstract}
Apstract: Članak otkriva uzroke i posledice nagomilanih problema u razvoju tekstilne industrije Ukrajine. Predstavljena je analiza stanja na globalnom tržištu tekstila. Proučavaju se procesi prenošenja uticajnih centara u industriji uglavnom iz razvijenih zemalja u zemlje u razvoju. Utvrđena je kritična zavisnost proizvodnje tekstila od uvezenih sirovina i poluproizvoda. Pažnja se skreće na potrebu jačanja domaće sirovinske baze, oživljavanja i gajenja lana, industrijske konoplje. Karakteriše se stanje sprovođenja spoljnotrgovinskih transakcija u industriji, istražuje se intenzitet protoka investicija za jačanje njegovog potencijala. Pažnja je usmerena na potrebu da se ojača uloga države u podršci razvoju tekstilne industrije. Razvijene su preporuke o daljem restrukturiranju tekstilne industrije kao efikasnog sredstva za povećanje njene konkurentnosti.
\end{abstract}

Ključne reči: spoljnotrgovinski promet, globalizacija, konkurentnost, nacionalno tržište, restrukturiranje, tekstilna industrija. 


\section{INTRODUCTION}

The world is changing. Some civilizations are disappearing; others are developing, becoming stronger. The bipolar world (USA - USSR) at the end of the twentieth century changed to a unipolar (USA). Nowadays, the key players in world politics and economics are the USA, Russia, China, as well as the EU and BRICS countries, "G7" and "G20". The ongoing changes in the political arena of the world, of course, affect the state of the world economy as a whole, and the economy of each state separately. Some countries are strengthening their economic potential, increasing their competitiveness, while other countries are losing ground in the global market. This problem concerns the market for industrial products, including light industry products and their component - the textile industry. In the proposed article, we intend to consider the situation in the global textile industry market. The focus will be on the causes and consequences of the restructuring of the textile industry of Ukraine after the collapse of the Soviet Union. For the period 1991-2020 Ukraine has transformed from an industrialized country into a raw materials appendage of the EU and other countries of the world. The textile industry is also in decline. We intend to consider the accumulated problems of the development of this industry and outline ways to solve them in Ukraine. Perhaps the results of our studies will be useful for economists in other countries.

\section{COMPETITION FOR LEADERSHIP IN THE WORLD TEXTILE PRODUCTS MARKET}

\subsection{Factors influencing the development of the textile industry}

Light industry products are not only a means of satisfying aesthetic needs or social identification, but also, essential goods for the population of any country in the world. Light industry is divided into textile and clothing, leather and fur, shoes (Fig. 1). For many centuries, the textile industry has acted as the most important sphere of production for most of the now developed countries of the world. It evolved under the influence of the scientific and technological revolution (STR), electrification, mechanization and automation of production, changes in the structure, needs and tastes of the population, etc. During the period of the scientific and technological revolution, for example, the rapid development of knitwear production was observed. It has become an important textile industry in most countries of Western Europe [1]. The textile industry combines the production of all types of fabrics, knitwear and other products; uses both agricultural raw materials and synthetic materials. The textile industry in its placement can focus on both raw materials and consumers. At the same time, you can trace the full cycle of deep processing for each type of feedstock - from semi-finished products to finished products.

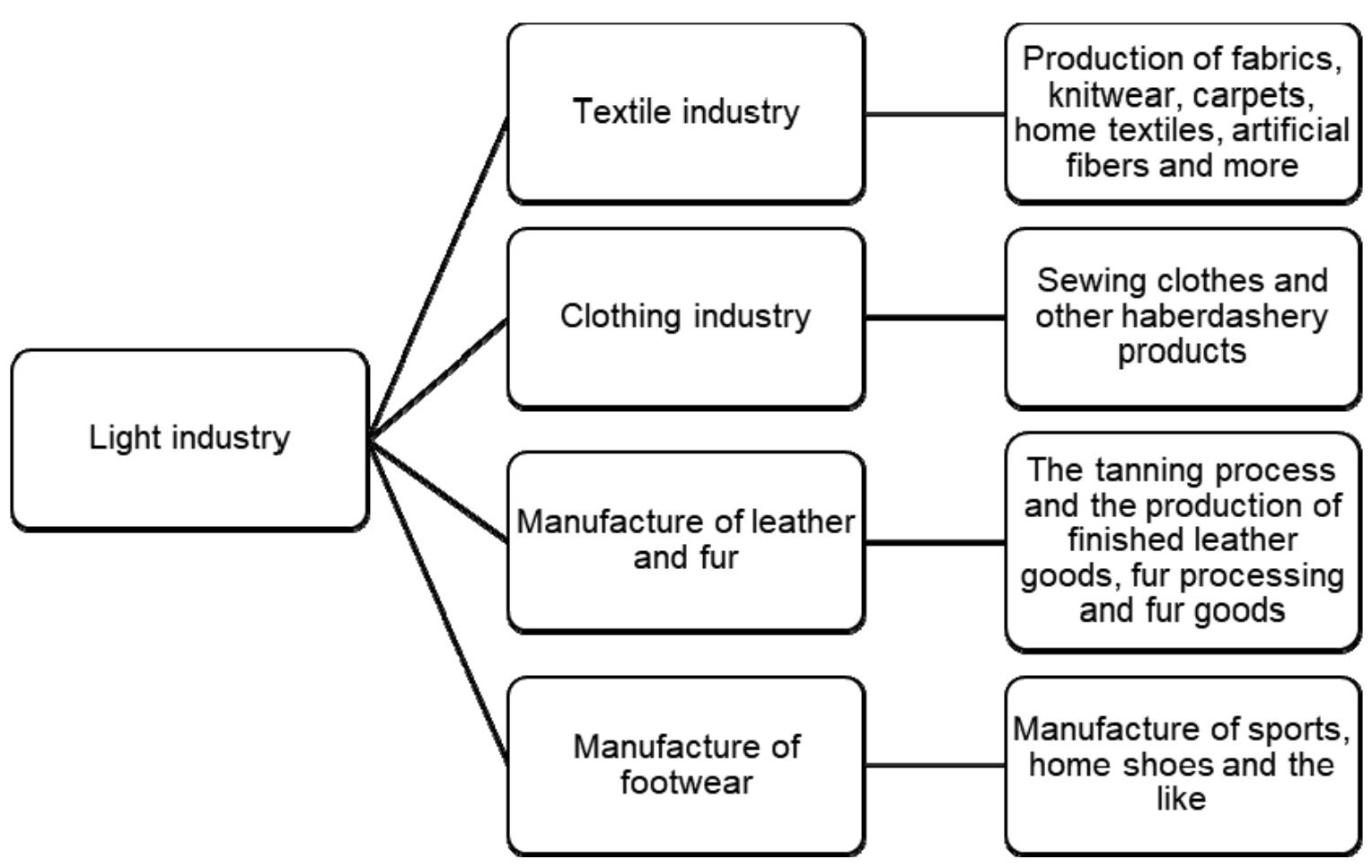

Figure 1: The structure of light industry 
The development of the textile industry solves several important problems: it satisfies the material needs of people, taking into account the specifics of demand; contributes to a more efficient use of labor resources in the areas where enterprises are located, primarily heavy metallurgy, since women mainly work at textile enterprises (up to 75\%); creates enterprises in areas that are limited by territorial, water and energy resources $[2,3]$. Over time, the textile industry began to lose its strategic importance and now it no longer belongs to industries that are developing rapidly. If at the beginning of the twentieth century its share in the structure of employment and gross output began to decrease, then already in the second half of the twentieth century the textile industry in many regions of the world was in a state of prolonged and deep crisis. During the period of industrialization of the countries of Latin America, Asia and Africa, the ratio between developed countries and developing countries began to change in the structure of the textile industry.

First of all, its development was significantly affected by the cost of labor and structural changes in the raw material base. We consider it necessary to pay attention to the fact that the cost of labor in these two groups of countries varies significantly. For example, if in the USA or countries of Western Europe the labor costs $\$ 10-22$ per hour, in developing countries it costs $\$ 0.24-0.60$. It was this factor that played a decisive role in the transfer of the textile industry from developed countries to developing countries. The textile industry developed unevenly in the countries of the world. For example, in India, Syria, Turkey, Mexico, Colombia, Brazil and Argentina, the textile industry arose in ancient times and developed gradually, evolved. In Asian countries, for example, in Thailand, it was formed in the second half of the twentieth century, but already on the basis of modern technology.

The EU textile industry is represented to a large extent by Germany, Spain, France, Italy and Portugal. In general, these countries produce about $20 \%$ of the world's textiles worth more than $\$ 160$ billion [4]. India is the third largest exporter of textile products, producing about $6 \%$ of the world's products in this industry. In Italy, light industry ranks second after engineering in terms of the number of employees, and the textile industry is of the greatest importance. Particular attention is paid to the production of knitwear, silk fabrics, yarn, chemical fibers, wool. Most textile enterprises are located in the north of the country, where they are provided with cheap electricity from alpine hydropower plants [5].

At the beginning of the XXI century, there was a process of rapid reduction in the production of textile industry in Western Europe. At the same time, output in developing countries was actively increasing. Particularly noticeable is the process of reducing the production of the industry in post-socialist countries, countries of Central and Eastern Europe.

Since the beginning of the XXI century, within the framework of the World Trade Organization (WTO), import quotas for textile goods have been canceled. This has led to an influx of European markets of cheap products from developing countries. Such processes have largely affected the Czech Republic, Poland and the Baltic countries. In these countries, business activity in the industry decreased, and sales of products decreased. Many European countries began to locate their production in countries with cheaper labor. To consolidate its own market position, it was practiced either the conclusion of alliances with large companies, or the deepening of production specialization to reduce production costs [6].

The textile industry in the underdeveloped countries is primarily focused on the production of raw materials and semi-finished products. They, in turn, are imported at fairly low prices to countries with high technology and the ability to process this raw material into a high-quality and expensive product for the end user. It is appropriate to emphasize that the experience of developing countries is no less important for Ukraine than the experience of developed countries. In the first case, developing countries show the importance of reorienting the assortment of the textile industry to the production of goods intended for the final buyer, that is, more profitable goods or goods with high added value.

Of course, the effectiveness of the functioning of the textile industry enterprises largely depends on the availability of high-tech and high-quality equipment. Due to the increasing influence in the developing countries' industries, more developed countries are intensively using automated and robotic technological equipment in order to reduce labor costs (labor intensity). These measures allow them to strengthen their market position in an atmosphere of fierce competition with countries that have cheaper labor.

\subsection{China is a leading player in the global textile market}

The textile industry is one of the most important sectors of the economy of China, Turkey, the USA, India and several other EU countries. The leading manufacturer of textiles in the global market is China. China is involved in all activities of the textile industry. The country is the largest exporter of these products, starting with raw materials, fibers and fabrics. China 


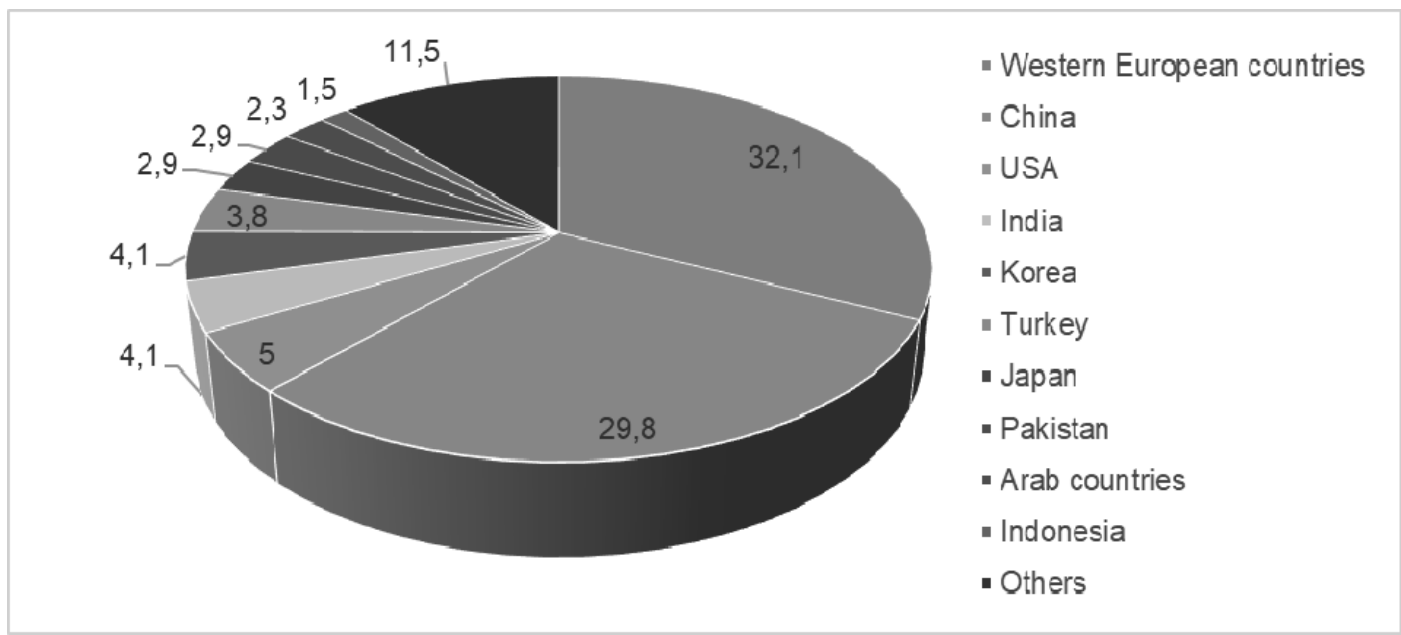

Figure 2: Top 10 textile exporters in the world [7]

produces about a quarter of the world's textile products and this figure continues to grow from year to year (Fig. 2).

Products under the brand name "Made in China" are mainly represented on the world market of textile products of the low and middle price segment. Although the global crisis of 2008-2009 and led to a decrease in textile exports, however, domestic retail trade recovered, per capita consumption of textile products continues to grow [5].

Of course, a separate topic of consideration is the functioning of the industry during the coronavirus period (2020). Chinese textile products are exported to almost all countries of the world. In the competition, China has gradually supplanted its most important rivals - Turkey and Mexico, which for a long time were the most important suppliers of textile products in the United States. A key factor in achieving the competitive advantage of Chinese products is their low cost. Every year, exports of Chinese textile products are growing at an average of $6 \%$. In 2008 alone, due to the global financial crisis, the export of Chinese textile products decreased by $9 \%$. In other countries, this decrease reached $16 \%$. With the restoration of the economic situation, the growth of Chinese textile exports amounted to $23.6 \%$, and clothing $-21 \%$ [8].

The economic policy of the state directs industry, including light industry, to export. The strategic goal of the Chinese government is to increase exports of high value-added goods and reduce exports of commodities. For this, diverse incentive measures are applied. It is, first of all, about the provision of soft targeted loans for the production of finished products with high added value, intended for sale abroad. Due to the achieved competitive advantages, China's light industry will continue to lead the world market for a long time.

However, there are certain risks faced by the Chinese textile industry. Firstly, it is an increase in material costs. The cost of cotton and synthetic fibers is increasing. The influence of this factor can cause a loss in the cheapness of goods. Secondly, the cost of labor increases, which is associated with the introduction of new labor legislation (2008). The average salary in China at the beginning of 2020 reached the level of 996 US dollars. This indicator is growing by about $50-70$ US dollars annually. Thirdly, recently there has been a significant shortage of qualified personnel. Low qualification of personnel acts as a brake in the production of high-quality products. Today, buyers tend to choose textiles at an affordable price, and good quality (price-quality). Finally, fourthly, an increase in the RMB exchange rate against the US dollar entails a rise in the cost of export of products [9].

\subsection{Key factors for textile development in Bangladesh}

The textile industry in Bangladesh is developing successfully. According to data from 2018, the country's population is about 159.5 million people. With a small territory (144 thousand sq. km.), Bangladesh is one of the most densely populated countries in the world. Bangladesh is one of the poorest countries in the region and the world. Factors forming the textile industry include: accumulated experience in this field, starting in the mid-70s of the last century; the competitive price of finished products is dictated by the availability of their own raw materials in the country and low wages of workers; a high percentage of young people; many factories have internships in 
South Korea and China; lack of duties on the markets of India, China, Korea and Malaysia; universality of factories for the production of various types of products.

As of 2017, about 4 million people are involved in the industry. The vast majority of workers in the industry are women. The country has more than 3,000 factories of various sizes and composition. They produce a different assortment of finished products: cut knitwear, textiles, knitted knitwear, outerwear, shoes and accessories, home textiles. Many factories specialize in the production of knitted fabrics, fabrics and yarn. There are also large vertically integrated full-cycle enterprises. Such enterprises enjoy state benefits and subsidies, unlike producers of medium and small businesses, as well as artisanal production, which is widespread throughout the country. The factors listed above determine not only the successful development of the industry as a whole, but also ensure the competitiveness of Bangladesh in the global textile market [10].

\subsection{Features of economic relations in the textile industry of the USA and Mexico}

For a long time, the US textile industry remained the most diversified and largest production segment. Since the beginning of the 20th century, most textile enterprises have been moved from the north-eastern region of the country to the southern states. Over $80 \%$ of the country's textile enterprises are concentrated here. The most influential sewing center in the United States is Los Angeles. His specialization is sewing women's dresses in accordance with Hollywood movie standards. In recent years, this industry has been faced with problems, the main one of which is the growing low-cost imports from Asian countries. As a result, the US is not able to deal effectively with this. On the other hand, the importance of Latin America, especially Mexico, in the supply of textile products to the American market is growing.

The North American Free Trade Agreement (NAF$T A, 1994)$ was based on the premise that the elimination of tariff and non-tariff barriers between Canada, Mexico and the United States would create an economic environment in which each country could use its competitive advantages. It was assumed that this transaction will combine the textile industry of the United States and Mexico to enhance competitive advantages in comparison with Asian countries. Contrary to expectations, the increase in clothing production in Mexico did not lead to a significant increase in the American textile industry. On the contrary, the US textile industry began to lose its competitive position. Since 1997, in this country there has been a decline in textile enterprises, declining profits, the bankruptcy of many factories, and an increase in the number of unemployed. Many business owners began to transfer their production facilities to Mexico, where the manufacture of textiles is more profitable due to the low cost of labor. Today, Mexico dominates the supply of textiles and ready-made clothing in the United States, displacing China in second place [1].

\section{TEXTILE INDUSTRY OF UKRAINE: STATE, PROBLEMS, PROSPECTS FOR DEVELOPMENT}

\subsection{The evolution of the textile industry in Ukraine}

In Ukraine, the textile industry began its development at the end of the XIX century. Most enterprises in the then tsarist Russia were small in terms of the number of employees and production volumes. An active revival of the industry was observed in Soviet times, when some enterprises were reconstructed, and new ones were built in cities such as Kiev, Zhytomyr, Chernigov, Rivne, Odessa, Poltava and others. More than $50 \%$ of the USSR textile industry was operating in Ukraine [11].

The textile industry of the Ukrainian SSR was provided with raw materials that were produced in the Union republics. For example, in the 1930s they solved the problem of a shortage of raw materials due to the creation of a kotonic industry in the republics of Central Asia, where up to 30 thousand tons of modified flax fiber were produced annually. Products produced at textile enterprises were in great demand among the population [12].

After the collapse of the USSR (1991), the textile industry began to disintegrate. The political factors were added by the loss of sales markets, outdated technology, deterioration of equipment, lack of personnel, etc. Demand for textiles began to plummet. One of the main reasons for this phenomenon was a significant decrease in the purchasing power of the population [13].

Ukraine's GDP even in 2019 amounted to only $65.8 \%$ of the 1990 level. Despite the fact that in 2000 there was a certain increase in the light and textile industries $-39 \%$, coat production - by $26 \%$, suits - by $29 \%$, however, the majority of accumulated problems in the textile industry have not been resolved [14]. According to the State Statistics Service of Ukraine, on 01.01.2019, the textile industry of Ukraine was 
represented by 510 enterprises and 15.9 thousand people. 1669 enterprises and 49.5 thousand people, 339 factories and 22.5 thousand people, respectively, are involved in the production of clothes, leather, and shoes [15].

The textile industry is represented by cotton, wool and linen production. Major business entities in the textile industry are: Cherkasy Silk Combine, Chernigov Cheksil, Rivne Flax Mill, Boguslavskaya Cloth Mill, Ternopol Teksterno, Kiev Knitwear Factory Roza, Rivne Nonwoven Fabric Factory, Kharkov Spinning and Weaving Factory society "Edelvika“ (Lutsk). The largest cotton mills are located in Kherson and Ternopol (cotton mills), Nikopol (spinning and yarn mill), as well as in Kiev, Kharkov, Chernivtsi, Ivano-Frankivsk, Lviv, Poltava, Kolomyia, Korostyshev and Radomyshl.

\subsection{Analysis of accumulated problems in the industry}

Existing problems in the development of the textile industry of Ukraine can be divided into three categories: 1) problems associated with industrial structures after the collapse of the USSR; 2) problems of the transition economy and the imperfection of domestic legislation; 3 ) problems of economic and social direction. Briefly describe each of these groups of problems. Firstly, within the framework of the integral economic complex of the USSR, most factories of the textile industry were aimed at performing only a limited volume of production and technical operations. They depended on a significant number of related industries and suppliers of necessary components. The level of interindustry exchange (cooperation) was about $70-80 \%$ of the output. After the collapse of the USSR, most factories severed ties with their main trading partners. For example, this affected the supply of different types of fabric from Russia and Belarus to Ukrainian factories. Secondly, there was an acute problem of providing raw materials with the loss of well-established relations with leading trading partners.

Until 1956, Southern Ukraine was the main producer of cotton for the entire Soviet Union. Subse- quently, there was a conversion of cotton to corn (?!). In the end, Ukraine was never able to restore its subindustry, which supplied raw materials for clothing manufacturers. Since Ukraine stopped growing cotton and producing chemical fibers, the main components for the production of clothing had to be imported from Uzbekistan, Belarus and other countries. More than $90 \%$ of all textile products in Ukraine began to be produced through tolling.

Domestic enterprises began to urgently need working capital, thanks to which the production of textile products begins. The sales system is not well adjusted. The Davalets company loads the production capacities of factories, which for the most part are idle due to the weakening of the domestic market and the loss of traditional markets for their products. It is calculated with a Ukrainian producer of a part of the product. Ukrainian entrepreneurs often only have the means to pay wages to their employees. At the same time, a foreign company makes significant profits by selling these products in markets, for example, in Western Europe. Thirdly, the problem arose of the wholesale distribution of goods in the industry. After the collapse of the USSR, the system of retail and wholesale distribution of textile goods was actually destroyed. Enterprises were forced to independently find ways to sell products [16]. As a result, in the 1990s, the number of stores specializing in the sale of clothing declined. There are new market players - spontaneous bazaars. Now the situation is gradually changing. More and more new stores and online stores are opening. Fourth, there was a need for equipment modernization, more active introduction of innovations in production [17]. The situation with the deterioration of fixed assets in industry in general and in the processing industry is presented in Table. 1.

The equipment of the processing industry is too outdated both morally and physically. Its updating is very slow. New equipment is known to be more competitive. Its use contributes to the use of significantly smaller amounts of resources. The cost of production is reduced, more products are produced. Fifth, previous problems are reflected in significant production costs, which makes textile products uncompetitive in

Table 1: The degree of depreciation of fixed assets, $\%[14$, c. 1]

\begin{tabular}{|l|c|c|c|c|c|}
\hline \multicolumn{1}{|c|}{ Industry } & $\mathbf{2 0 1 3}$ & $\mathbf{2 0 1 4}$ & $\mathbf{2 0 1 5}$ & $\mathbf{2 0 1 6}$ & $\mathbf{2 0 1 7}$ \\
\hline Industry & 56,9 & 60,3 & 76,9 & 69,4 & 59,1 \\
\hline Manufacturing industry & 50,1 & 56,9 & 75,8 & 76,4 & 64,6 \\
\hline
\end{tabular}


both the domestic and global markets. Sixth, an unresolved issue is the almost unhindered flow of contraband. According to experts, at least $70 \%$ of contraband clothing is sold in bazaars. About $40-60 \%$ of shadow goods come to Ukraine from countries such as Turkey, China and Poland. According to experts, the reasons that led to the decline in textile production include the following: unfair competition from imported goods, the existence of a "shadow" production sector, and trade in low-quality "smuggling" - 30\%; insufficient solvency of the population - $20 \%$; ill-conceived privatization of enterprises, disaggregation or despecialization of production - $16 \%$; unfavorable investment climate and the absence of a rationally thought out investment policy - 13\%; low technical level of equipment at enterprises and dependence on imported raw materials and materials - $11 \%$; ill-conceived organization of production and marketing of products, as well as worsening working conditions of domestic producers, stopping wholesale trade after the liquidation of regional wholesale bases, monetary ways of regulating the exchange rate $-10 \%$ [18].

The solution of these problems can and should help to stabilize the development of the industry, increase the competitiveness of products, and the Ukrainian textile to enter the international market.

\subsection{The need for restructuring the raw materials base of textiles}

Let us highlight the following arguments regarding the feasibility of simultaneously raising both the agrarian and textile sectors. Firstly, the textile industry alone will not be able to play an important role in the development of the economy unless its material and human resources are combined, if there is no adequately developed effective national policy in this area. Secondly, with the development of the raw materials base of the textile industry, the process of specialization will be activated, which will ensure high competitiveness of textile production.

Thirdly, the underdevelopment of the textile industry will continue to lead to an increasing dependence of Ukraine on foreign manufacturers. At the same time, the existence of its own raw material base, the combined efforts of agriculture and industry will contribute to creating a base for creating competitive advantages in the textile industry. The rational use of potential when combining agricultural and textile production in the near future can significantly improve the situation not only in these two areas, but also in other sectors of the economy that use textile products.
As has been repeatedly noted, most Ukrainian enterprises operate on tolling raw materials. The use by foreign firms of the capacities of Ukrainian factories contributes to the fact that incoming capital in Ukraine ultimately leaves it. He leaves her with added value, which was created in Ukraine using domestic resources. In such an indirect way, foreign businessmen use its equipment, energy, labor and many other resources in Ukraine, even despite the high probability of economic risks. Foreign businessmen in Ukraine are attracted by the low cost of labor, low prices for the purchase of agricultural raw materials and low fees for the use of equipment and technologies.

Thus, the low purchase price of textile goods does not correspond to the actual actual cost, which is actually much higher.The textile industry did not provide timely support to the agricultural sector of the production of raw materials (flax, cotton and sheep breeding). As a result, the main factor $(90 \%)$ reduction in the production of textile factories is the lack of domestic raw materials. Cotton for domestic producers is exclusively imported raw materials. In this situation, to plan in detail the work of cotton enterprises, to develop a strategic policy, is not advisable and risky. Flax can become an alternative to cotton for Ukraine. By the way, linen products have higher protective properties compared to cotton. The main emphasis should be placed on the revival and gradual development of the raw material textile base in Ukraine (Table 2). Over the years of independence, Ukraine has lost its traditional markets, which affected the actually destroyed own raw material base.

Table 2: Dynamics of sown areas of flax fibre and cannabis sativa in Ukraine, thousand ha $[19$, c. 15]

\begin{tabular}{|c|c|c|}
\hline Year & Flax fibre & Cannabis sativa \\
\hline 1990 & 172,5 & 10,2 \\
\hline 1995 & 97,8 & 6,7 \\
\hline 2000 & 23,4 & 3,0 \\
\hline 2005 & 25,5 & 0,9 \\
\hline 2010 & 1,3 & 0,8 \\
\hline 2015 & 1,7 & 1,7 \\
\hline 2016 & 1,7 & 3,5 \\
\hline 2017 & 1,5 & 2,7 \\
\hline 2018 & 1,7 & 1,3 \\
\hline
\end{tabular}

For a radical change in the situation, agricultural production of raw materials should be transferred 
to an industrial basis. It is necessary to constantly increase the productivity of flax and sheep husbandry, implement new farming systems, introduce new technologies for the production and processing of cotton, and strengthen and maintain the genetic fund of Ukraine. It should be noted that the leading role in these matters belongs precisely to investment policy, which should ensure an increase in the level of efficiency, in the first place, of those sectors that are lagging behind in development (production of raw materials). In addition, the investment policy should contribute to the creation of an alliance development system based on the rationalization and optimization of all investments in the resource and processing sectors. To create a powerful raw material base, it is necessary to pay attention to the technical re-equipment and reconstruction of existing facilities [20]. Greater improvement is required in the organization of the production of textile raw materials, procurement and transportation, storage in warehouses, etc. [6].

It is the integrated agrotextile alliances that can play a decisive role in this matter.

\subsection{Foreign economic activity of textile enterprises}

Let us analyze the state of foreign trade transactions in the light industry, including the textile industry, for the period 2015-2019 (Fig. 3). According to Ukrlegprom [21], the production of light industry products in the country is in critical condition. The export situation is unstable and ambiguous. After the rise in 2017, a gradual decrease in export of products is observed. Import revenue is growing annually. In its structure, a derogatory, in our opinion, second-hand one prevails.

In Ukraine's commodity imports as of 2018, the share of light industry is $4.7 \%$, exports $-2.6 \%$. The leading countries in importing products are China $(27.4 \%)$, Poland (10.2\%), Turkey $(9.2 \%)$, Germany $(8.2 \%)$ and Italy (7.1\%) [21]. Textiles and clothing (mainly China) and shoes (China and Italy) are mainly imported to Ukraine. Most of all, in 2018, synthetic threads were imported to Ukraine $-10.55 \%$, shoes and leggings $-12.69 \%$. Import of textile materials for technical purposes amounted to $5.42 \%$, clothing $9.10 \%$, other finished textile products - 10.15\% [15]. Ukraine exports textile products mainly on the basis of tolling raw materials, and at the same time acts as an intermediary-producer for other countries. In 2018, foreign trade turnover in light industry amounted to 104.5 billion US dollars, which is $12.4 \%$ more than in 2017. Import volumes in 2018 amounted to 57.1 billion US dollars, an increase of $115.2 \%$.

According to the State Statistics Service of Ukraine, in 2019 the volume of export deliveries of light industry products decreased compared to 2018 and amounted to $\$ 35.5$ million $(-2.9 \%)$. The decrease in foreign trade transactions occurred in all major product groups. Total export deliveries amounted to shoes - \$20.1 million (-10.3\%); textile clothing - \$ 12.5 million (-3.1\%); knitted clothes - \$12.2 million $(-9.0 \%)$; fur raw materials - $\$ 6.7$ million $(-25.5 \%)$; hides and unprocessed leather $-\$ 6.1$ million $(-6.9 \%)$. On the contrary, imports of light industry products continue to flourish. Deliveries in 2019 compared to 2018 amounted to $\$ 467.9$ million $(+17.6 \%)$, including: knitted clothing - by $\$ 137.8(+52.9 \%)$; textile

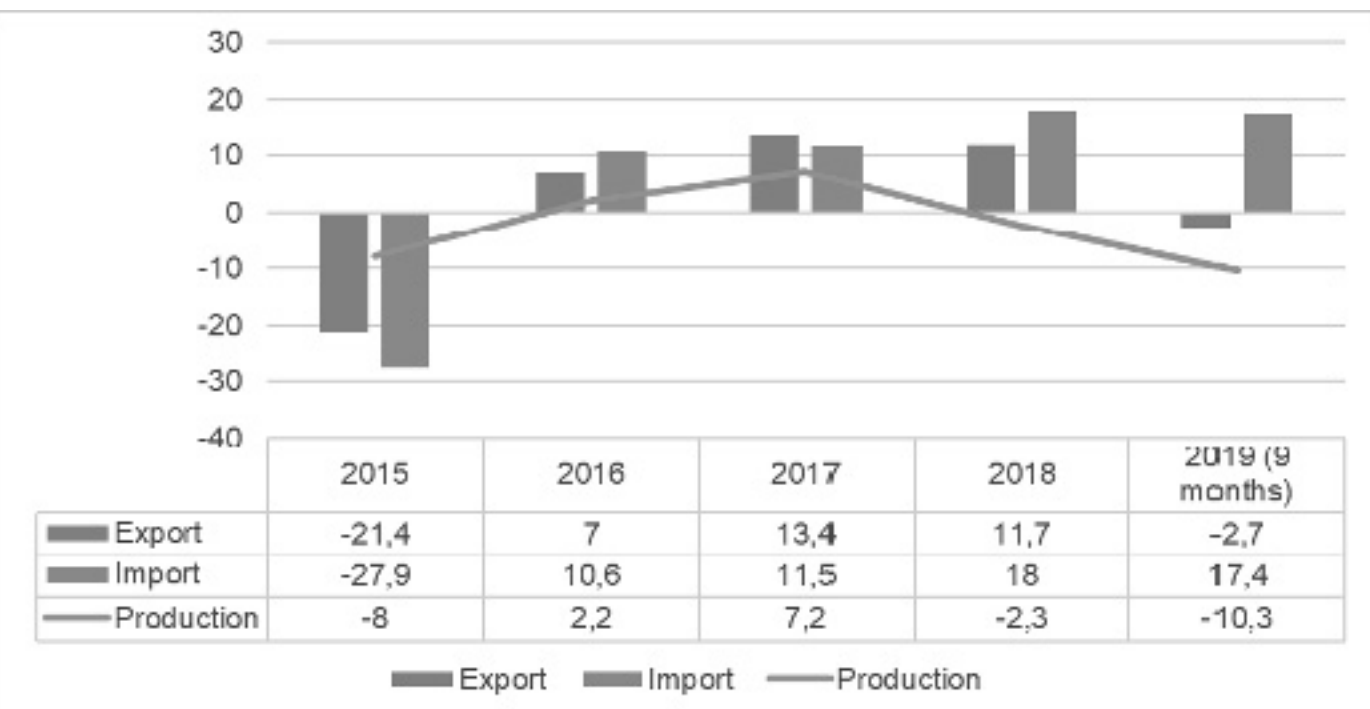

Figure 3: Dynamics of growth / decline of indicators, \% compared to the previous year 
clothes - by 128.1 dollars (+ 52.9\%); shoes - \$ 100.9 (+ 29.9\%); knitted fabrics - by 84.1 dollars (+ 73.4\%); other textiles - by 83.0 million dollars (+ $30.7 \%)$. It is not difficult to calculate that import volumes exceed export volumes by 13.18 times [15]. This indicator reflects the essence of state policy in the field of protection and development of the domestic market for light and textile products.

A significant factor in the development of the textile industry may be the flow of investment from domestic and foreign investors. The total volume of capital investments in the textile industry is insignificant and makes up only $0.92 \%$ of the total volume of investments in the state economy in 2018. Investments in other areas are invested much more intensively: in the mining industry and quarrying $-27.0 \%$, the supply of electricity, gas and air conditioning $-20.9 \%$, the production of food, beverages and tobacco - 15.12\%. Investors send funds to those industries where you can quickly and with the lowest risk receive income. The textile industry does not belong to this category. During the year 2018, UAH 1,846 million was invested in textile production, the production of clothes, leather, products from it and other materials. The largest amount of investments was directed to textile production, located in Khmelnitsky (12.7\% of the total), Chernivtsi (7.4\%), Lviv (6.1\%), Transcarpathian (5.0\%) and Zhytomyr (4.7\%) areas [15].

Foreign investors are in no hurry to invest in the industry of Ukraine. For example, in 2017, only 6,206.4 million UAH was invested in the industrial sector, or $1.4 \%$ of all capital investments. Of these funds, approximately $0.3 \%$ was directed to light industry, $32.3 \%$ to heavy industry, and $27.4 \%$ to processing industry (2015 data). The textile industry is invested mainly by investors from Germany, Romania and Sweden, and those who subsequently buy goods of this industry in Ukraine [21].

\subsection{Directions for increasing competitiveness of the textile industry}

Textile industry for sustainable development needs support, first of all, from the state. The importance and priority of the textile industry for the country's economy is due to the following factors: the ability to satisfy society's need for consumer goods and basic necessities, to improve the quality of life of Ukrainians; connectedness with many related areas and the ability to serve the entire economic complex of the country; large capacity of the domestic market for goods in the industry; high level of added value (up to 50\%); quick capital turnover; low energy intensity of production.

Let us dwell on possible ways to solve problems that have accumulated in the industry. Firstly, it concerns the protection of the national producer. The vast majority of countries in the world are forced to import mainly those goods that are either absent or lacking in the domestic market. In addition, countries set quotas for the import of those goods that are produced in the country $[22,23]$.

In Ukraine, there is a need to develop relevant laws and regulations on these issues. It is advisable to create such conditions of trade that would protect the domestic market (protectionism policy) [24, 25]. For example, if in domestic manufacturers the margin for products is $20-25 \%$, then among manufacturers in the Baltic states $-18 \%$. It is clear that a large margin on finished products becomes a big obstacle to its implementation [10]. Not always finished products get from the factory to the store. A situation is possible when these products are returned in the form of imported goods, which lay on the shelves of foreign stores and did not "find" their buyer. We consider it quite advisable to reorient textile production towards middle-income buyers. Since most Ukrainians have an average or low income level, cheap products are in demand among the population. The main competitors of domestic products are cheap goods from Turkey and China, as well as second-hand goods, which are imported in thousands of tons from Western Europe. It is advisable for Ukrainian manufacturers to focus on the middle class and produce most of the products specifically for people with average incomes. Middle-income buyers prefer to buy quality products, perhaps even at a high price, rather than cheap, low quality.

Thirdly, we should not forget about the principle of "returning" to our domestic market and then final consolidation on it. After the financial crises of 19971998. and 2008-2009 Although Ukrainian manufacturers managed to fill the vacant niches from importers affected by the crisis, it is becoming increasingly difficult to maintain these positions due to cheap foreign products.

Fourth, the marketing and financial strategies for market behavior for domestic factories are in need of improvement. In most cases, such strategies are absent or implemented inefficiently. The reason is the lack of skilled workers. Domestic manufacturers are not sufficiently aware of the methods of optimal and effective financial management. It is necessary to carry out a re-qualification of financial management, to study in depth international financial reporting 
standards. The financial literacy of industry workers should also be enhanced. Domestic companies are not sufficiently oriented in matters of "finding" financial resources for introducing new products at the enterprise $[24,25]$.

Fifthly, it is necessary to switch from raw materials supplied to customers to domestic raw materials (flax, hemp, wool). It is advisable to develop a set of measures to develop their own raw material base, which requires deep structural transformations in the economy. Measures should be taken aimed at the simultaneous development of both the textile industry and its raw material base. Such an approach will help to more widely satisfy the existing needs of the market, strengthen mutual responsibility, and efficient use of resources. It is advisable to create integrated agrarian and textile production. They will cover the entire technological chain from the production of raw materials by agriculture to the production and sale of textile products in the domestic and foreign markets. The organizational form of such a community can be strategic agrotextile alliances [26].

So, the state can contribute to the further development of the textile industry in the following main areas: attracting foreign investment and increasing the activity of domestic investors; restriction of import of imported products and saturation of the domestic market with competitive domestic products; the withdrawal of a significant part of textile production from the "shadow" sector of the economy; reduction of duties on import of high-quality imported raw materials and at the same time increase in duties on second-hand; provision of benefits to industry enterprises (reduction in tax rates, deferred payment of payments); raising wages in the industry to increase its prestige; provided benefits or subsidies for the renewal and purchase of fixed assets; restructuring of production processes; updating fixed assets; development of the latest and high-performance clothing manufacturing methods; staff development.

\section{CONCLUSION}

Summing up the state of the textile industry of Ukraine, analysis of problems and prospects for the development of the industry, we note that the development of its raw material base is a necessary and priority condition for the development of the textile industry and light industry as a whole. The industry needs a large-scale introduction of innovations, restructuring of production. It is necessary to improve the personnel potential at the enterprises of the textile industry. It is advisable to develop a set of meas- ures aimed at introducing a system of financial support for the industry on a state and commercial basis. Access to the domestic market of imported textile products and raw materials, second-hand should be limited by improving tariff and non-tariff methods of regulating export-import operations to the benefit of the development of domestic textile production.

\section{REFERENCE}

[1] Karasev, P. A. (2011). Foreign experience of innovative development of light industry - secrets of success in global competition, Transport Business of Russia, 11 (96), 94-103.

[2] Burdenko, E. V (2015). The influence of industrial policy and regionalization on the development of light industry in Russia, Moscow, Publishing House "Pero".

[3] Stefanović, V., Urošević, S. (2019). The impact of harmfulness in work process on safety and health of employed women with regard to the textile industry. Tekstilna industrija, 67 (3), 4-13.

[4] Mokhova, Yu. L. (2018). European experience of state regulation of light industry. Scientific notes of Tavriya National University named after VI Vernadsky. Public Administration Series, 29(68): 6, 65-69.

[5] Epanchintseva S. E. (2012). Light industry development: experience of foreign countries. Bulletin of KazEU, 1, 21-26.

[6] Burdenko, E.V.,Miguleva, A.A. (2012). A retrospective analysis of the development of organizational forms in the textile industry, Scientific journal "Design and Technology", 32, 132-138.

[7] Global Textile Industry Business (https://www. textileinfomedia.com/global-textile-listing, available: 05/07/2020).

[8] Motuz, S., Nikitina, L., Yuan, Z. (2015). Upon the issue about the textile and clothing industry development in PRC, International Journal of Applied Engineering Research, 20(10), 41011-41017.

[9] Yuan, Ch., Nikitina, L. N. (2015). The main determinants of China's light industry competitiveness, University proceedings: Light industry technology, 3, 43-47.

[10] Bykov, I. M. (2019). Textile industry of Bangladesh. Attractiveness to Russian Entrepreneurs, Young Scientist, 7 (245), 19-21. 
[11] Vinar, B. (1976). Textile industry. Encyclopedia of Ukrainian studies. Slovnikova Chastin (EU-II), Paris, New York, 8, 3159-3166.

[12] Burdenko, E. V. (2016). The industrial policy in the field of light industry, carried out in the USSR, International Research Journal, 5 (47), 41-44.

[13] Andros, S. V., Gerasymchuk, V. H. (2018). Influence of Free Trade and Protectionism on the Development of Textile Industry. Tekstilna Industrija, 66 (4), 58-68.

[14] Omelchenko, V. D. (2002). Problems regarding the competitiveness of Ukrainian light industry products. Light industry, 3, 51.

[15] State Statistics Service of Ukraine (http://www. ukrstat.gov.ua/operativ/ operativ2007/pr/orp/orp_ u/arh_orp_u.html, available: 05/08/2020).

[16] Kuzmina, N. N. (2015). Trends in the development of textile and light industry, taking into account global trends in the organization of production and promotion of goods on the market. Bulletin of Altai Science, 3-4 (25-26), 285-290.

[17] Ternova, A. S, Sirenko, S. S. (2016). Innovative aspects of the competitiveness of light industry enterprises. Global and National Economic Problems, 13, 196-200.

[18] Naumova, L. M. (2013). Strategic priorities and mechanisms of development of the textile industry and its raw material base, Economic innovations, $54,179-188$.

[19] Crop production of Ukraine. (2019). Statistical collection. Responsible for the release of $\mathrm{O}$.
Prokopenko. Kyiv: State Statistics Service of Ukraine, 220.

[20] Burdenko, E. V., Miguleva, A. A. (2012). Theoretical aspects of the restructuring of textile enterprises, Scientific journal "Design and Technology", 29, 106111.

[21] Ukrlegprom (https://ukrlegprom.org/ua/ analytics/, available: 05/08/2020).

[22] Buzhak, Yu. S. (2014). Adaptation of foreign experience in taxation of imports of light industry goods to domestic conditions, Agrosvit, 22, 73-79.

[23] Izovit, T. L. (2015). The effect of the introduction of additional import duties on the development of light industry, Economy and State, 8, 54-57.

[24] Lisyutin, A. I. (2018). State mechanisms of influence on the development of light industry in Ukraine. Public administration in Ukraine. Series „Public Administration", 5, 57-63.

[25] Balueva, O. V, Lisyutin, A. I. (2019). International experience of state regulation of light industry. Collection of scientific works of DonSUU, Series "Public Administration", 20(310), 6-17.

[26] Grishchenko, I. M. (2015). Light industry of Ukraine: realities and prospects of development. Expert-analytical report. Kyiv: KNUTD, 82.

Rad primljen: 10.05.2020.

Rad prihvaćen: 05.06.2020. 